\title{
Emirati General Education Pre-service Teachers' Preparedness for Diversity in Inclusive Classrooms
}

\author{
Sumaya $\operatorname{Saqr}^{1} \&$ Lilly Tennant ${ }^{1, *}$ \\ ${ }^{1}$ Emirates College for Advanced Education, P.O. Box 126662, Abu Dhabi, United Arab \\ Emirates \\ *Corresponding author: Emirates College for Advanced Education, P.O. Box 126662, Abu \\ Dhabi, United Arab Emirates. E-mail: 1tennant@ecae.ac.ae
}

Received: April 28, 2016 Accepted: May 23, 2016 Published: June 23, 2016

doi:10.5296/ije.v8i2.9396 URL: http://dx.doi.org/10.5296/ije.v8i2.9396

\begin{abstract}
Today's general education classrooms continue to become increasingly diverse. Educational diversity and the high expectations for all learners have a profound impact on pre-service teacher preparation. This paper explores Emirati general education pre-service teachers' perception of preparedness to effectively instruct diverse learners including those with exceptionalities. Individual and focus group interviews and student teaching internship portfolios were used to examine Emirati pre-service teachers' beliefs about their roles and responsibilities in the diverse classrooms of today. Findings shed light on the impact of teacher preparation on their perceived readiness, willingness, and abilities to meet the wide range of learner needs through inclusive practices. Moreover, several areas presented challenges to the pre-service teachers during their teaching practice. The study also identified issues with current teacher preparation practices, program coordination or collaboration efforts, and practicum experience necessary for pre-service teachers. Based on the findings, recommendations for reassessing the content and structure of higher education teacher preparation programs are discussed.
\end{abstract}

Keywords: teachers, inclusive classrooms, diversity, United Arab Emirates (UAE), inclusion, special education 


\section{Introduction}

Inclusion is a right and is essential to a well-functioning society. Inclusion promotes quality education for all, including those who might be marginalized due to disability, emotional/ behavioral problems, giftedness, hearing or visual impairment, and language delay. Although this is a big challenge for all, it is an opportunity to advance the school as a change factor promoting dialogue and participation, making possible well-being through an education of quality for all without exception, and for the commitment of the community. The process of inclusion requires the general classroom teacher to have certain knowledge and understanding regarding the needs of diverse learners including those with specific disabilities, teaching techniques and curriculum strategies. Hence, "the task of initial teacher education is to prepare people to enter a profession which accepts individual and collective responsibility for improving the learning and participation of all children" (Florian \& Rouse, 2009, p. 596).

Teachers play a major role in quality education and "the quality of an education system cannot exceed the quality of its teachers" (Mckinsey \& Company, as cited in Savolanien, 2009, p. 16). In addition, Sanders \& Horn (1998) suggest that, among school-related factors, teacher's quality has a greater impact on learner achievement than any other factor. The need for effective and high quality teachers prepared to meet the diverse needs of all learners is obvious so as to provide equal educational opportunities, access, participation, and achievement for all in an inclusive society. Teachers do matter as the knowledge, beliefs and values they bring to bear in creating an effective learning environment, make the teacher a great influence in education for inclusion and the development of the inclusive school. Therefore, the focus on initial teacher education ' ... would seem to provide the best means to create a new generation of teachers who will ensure the successful implementation of inclusive policies and practices' (Cardona, 2009, p. 35).

More recently, the Emirati society expects schools and teachers to continuously respond efficiently to increasing expectations such as addressing different student backgrounds, being sensitive to cultural and gender issues, enhancing positive social and intellectual dispositions, responding effectively to students with learning difficulties or behavioral problems, integrating technology, and keeping up with the rapid advancement of knowledge and approaches to student assessment of learning and engagement. Consequently, teachers have to be confident, competent, knowledgeable, and professional in inclusive education in order to meet the challenges they will encounter in the present 21 st century school climate (Carroll, Forlin, \& Jobling, 2003).

Pre-service teacher education has a crucial role to play in developing successful inclusive educational practices. Although available research demonstrates that field experience provides pre-service teachers a supervised opportunity to apply their learning to a practical work experience and also 'learn the profession' and reduces the anxiety of beginning teachers (Rice, 2003), little research is available in regards to the contribution of teaching practice and the contribution of coursework on the development of pre-service teachers' knowledge and skills (Rice, 2003; Wilson, Floden, \& Ferrini-Mundy, 2001). 
Therefore, the major intent of the study is to investigate the preparedness of the pre-service Emirati teachers to respond to the challenge of diversity in inclusive classrooms during their student teaching or internship in public schools. Determining the level of preparation of these pre-service teachers via their initial training to be 'inclusive' would assist them in their career development and planning, their transition to employment, further education and training, and in developing a disposition to lifelong learning.

\section{Research Context}

\subsection{Educational Rights in the UAE}

The UAE is a relatively young country, formed in 1971. Due to the novelty of its public education system, special needs education has only recently been introduced. However, education has always been one of the country's highest priorities. The government of the UAE recognizes the need to support students with special needs. This recognition has its foundation in the UAE constitution which was drafted in 1971 as an interim constitution; this was later amended to become permanent in 1996 (UAE Cabinet, 2010; Al Ahbabi, 2009). Article 17 of the constitution declares that education is fundamental to the progress of society and is to be compulsory at the primary level and free at all levels (Constitution of the UAE, n. d.).

The UAE Cabinet Resolution No. 1 of 1977, was one of the first laws related to people with disabilities, the government first supported these individuals through direct financial assistance and the establishment of rehabilitation centers administered by the Ministry of Labor and Social Affairs. A person with a disability was broadly defined as "one who has a disability that hinders a person totally or partially from participating in life" (Rashed \& Ahmed, 1995, p. 99). In 1979, the first special education classroom was established with forty students, and special needs teacher training also began at the same time at United Arab Emirates University (Al Ahbabi, 2009). In 1988 Federal Law No. 2/385 set forth guidelines for special education classes. Federal Law No. 29 of 2006 (In Respect of the Rights of People with Special Needs), guarantees rights for people with special needs as schools may not discriminate or refuse admission based on learning difficulties or special needs. Implementation of this law has been slow, but is compulsory for both private and public schools. Articles 12 and 15 (The Disability Act), of the same Law, specified that "the country assures equivalent education chances for the person with special needs in all educational establishments....it shall be in the regular classes or in special classes" which promotes the philosophy of inclusive education (Gaad, 2011, p.4). The philosophy of inclusion is supported by the UAE Ministry of Education. Now, with the introduction of this UAE Federal Law No. 29 in 2006 and ensuring that all students with disabilities in public and private educational institutions in the UAE have access to equal educational opportunities, the number of students with intellectual disabilities being included in general education schools is increasing (Ministry of Education, 2010).

As there is movement toward more inclusive schooling in almost every country (The Salamanca, Statement, (1994), preparing new teachers for inclusion has become a key issue. 
According to Rose (2007), teacher training colleges have had to review the courses offered to ensure that teachers are prepared to work with students from increasingly diverse learning backgrounds. Forlin (2007), found that several teacher education institutions are slow to respond to this need and that newly qualified teachers continue to suggest that they are insufficiently prepared to meet the needs of all students within inclusive classrooms.

\subsection{Student Diversity}

To maximize learning, the teacher needs to understand each individual in the classroom. The increasing diversity of today's classroom makes teaching a very complex activity. Teachers are required to recognize and respond to each student's educational needs and parents' expectations, and must be sensitive to community and family values. Different types of diversity exist within classroom settings; racial, ethnic, religious, physical, learning, intellectual, linguistic, behavior, emotional, and personality (Schwartz \& Karge, 1996). An essential component of successful inclusive settings is the effective management of the classroom and the effective instruction provided by the teacher to meet the wide range of needs of students (Voltz, Brazil, \& Ford, 2001). Therefore, the challenge for teachers is to break the mold and model effective approaches to teaching and learning to meet the needs of every learner.

Abu Dhabi Education Council (ADEC) believes that all children can learn and that the responsibility for educating all students to their fullest potential rests with school staff working within a supportive educational environment. It is expected that the curriculum and the educational programs which most students with special educational needs (SEN) should be able to access and derive benefit from, can be provided in public schools which the student would normally attend. The diverse learners include students with learning difficulties and disabilities, and those who are gifted and talented. The classroom teacher is part of the Learning Support Team (LST) in each school. Therefore, it is expected that the classroom teacher needs to make curricular accommodations for students with varying abilities in the inclusive classroom. Consequently, prospective teachers need to be aware of this expectation and understand the key role they have within whole school initiatives to improve outcomes for learners with additional learning and support needs (Abu Dhabi Education Council, 2010).

\subsection{Teaching Practice}

Teaching experience constitutes an integral part of teacher education. Hagger and McIntyre (2006) emphasize its importance, as they believe that "whatever student teachers need to learn to do as teachers in schools for their future careers, it is in schools that they need to learn to do these things" (p. 65). Therefore, they suggest that pre-service teachers' school-based learning ought to be designed as a planned curriculum with carefully designed diverse learning experiences to develop appropriate expertise. They also stress the need for pre-service teachers to practice engaging in "serious and informed intellectual analysis" of their teaching and the way it can be improved as something which they do in schools. The importance of practical experience is also stressed by other researchers for the important role it plays in shaping future educational practices, and providing an opportunity to address the 
research-to-practice gap (Boger \& Boger, 2000; Cook \& Cook, 2004; Cook, Landrum, Tankersly, \& Kauffman, 2003).

Teacher education programs have to consider placements in inclusive schools and classrooms embracing inclusion as a philosophy and in practice and where pre-service teachers can get enough appropriate support in order to ensure a successful experience. These programs also need to address providing pre-service teachers opportunities to examine and foster their beliefs and then learn how to address diversity in the classroom (Jordan, Schwartz, \& McGhie-Richmond, 2009).

Spandagou, Evans, and Little (2008) noticed a considerable difference in the perception of personal preparedness of pre-service teachers perhaps associated with the characteristics of the in-school experience component. Lancaster and Bain (2007) also noticed that the one-to-one student mentoring experience led to increased self-efficacy when compared with the inclusive classroom support experience or the university or college-based program. Provision of opportunities to reflect on favorable outcomes in realistic teaching situations can also improve confidence and future success (Loreman, Deppeler, \& Harvey, 2005).

Research on cognition recommends that acquiring practical or situated knowledge (derived from doing) ought to precede competent application of what has been learned (Talvite, Peltokallio, \& Mannisto, 2000). Hence, teaching practice provides an opportunity for future teachers to utilize and own their knowledge and further develop their abilities and confidence.

\section{Method}

The overall purpose of the research was to investigate Emirati general education pre-service teachers' level of preparedness in meeting the needs of diverse learners during their internship. A qualitative approach was selected to explore the prospective teachers' experiences of teaching and leading their inclusive classrooms. Experience is a phenomenon of interest for qualitative researchers, particularly the phenomenologists. Qualitative approaches are designed to obtain maximum information from the participants in their natural settings. Qualitative research designs enhance rich data collection and are identified as appropriate for data analysis in new areas of research (Patton, 1990). This kind of research approach provided avenue to pre-service teachers to express their feelings, opinions, and experiences in teaching and supporting diverse learners during their internship.

\subsection{Participants and Program Structure}

The data were derived from a sample of ten fourth year Bachelor of Education (B.Ed) students of a teachers' college who were engaged in teaching a ten-week internship in inclusive classrooms. These pre-service teachers had taken a college course on exceptional learners in the semester prior to their internship placement. The college has a teacher preparation curriculum in which students can receive professional certification to teach English, mathematics, and science at the elementary level. In order to become certified, pre-service teachers have to successfully complete 20 weeks of practical experience in the 
schools over the course of the degree, under the supervision of a college faculty mentor and a school mentor teacher.

Prior to beginning student teaching, pre-service teachers are engaged in coursework that equips them with skills, knowledge, and understanding needed to succeed in the classroom. College mentors aid them in transitioning this formal knowledge or learning into practical knowledge or action. In this supervisory model college mentors, mentor teachers, and pre-service teachers work together to assess teaching performance and to share decision making about pre-service teachers' field experiences.

The pre-service teachers were prepared for a role involving a collaboration-consultation, a form of collaboration in which they, as general education teachers, request services of special education teachers to help generate ideas to address ongoing situations. Given that teachers have a great impact on their students, it is important to consider how prospective teachers position themselves regarding meeting the needs of gifted and other academically diverse learners in schools through differentiating instruction, and engaging with others in the school community.

This research study employed different data sources. The relatively small sample provided rich data and reasonable coverage of the phenomenon given the purpose of the research study and the interests of the stakeholders. While the researchers gathered data to the point that made them feel nothing new could be added, saturation was reached. In the Sample Size section of his work on qualitative research methodology, Patton (2002) stated,

.... There are no rules for sample size in qualitative inquiry. Sample size depends on what you want to know, the purpose of the inquiry, what's at stake, what will be useful, what will have credibility, and what can be done with available time and resources. (pp. 242-243).

In addition to the nature and scope of the researchers, the time and quality of interviews, the number of interviews per participant, the sampling procedure, and researchers' experience influenced the sample size needed to reach saturation (Lincoln \& Guba, 1985; Patton, 2002; Strauss \& Corbin, 1990).

\subsection{Data Collection Methods}

A combination of several data collection methodologies, known as data triangulation, was applied to this study and it served to strengthen its results (Patton, 1990). The purpose of the triangulation data collection methods used in this study was not only to limit or reduce the opportunities of bias that may occur when only using one data collection method, but also to support the study in terms of logical generalizations related to emerging trends, patterns or themes (Maxwell, 1996). For purposes of informing this study, the data collection methods that were utilized include semi-structured interviews, focus group discussions, and reviews of internship portfolios.

\subsection{Semi-structured Interviews}

A semi-structured interview method was employed (Kvale, 1996). An interview guide, consisting of 11 open-ended questions with probes was used to gain insights on pre-service 
teachers' opinions, concerns, feelings, and level of preparedness for inclusive education. The interview guide was developed through a review of the literature relating to teacher preparation for inclusive education. Participants who consented to share their experiences working with children with special needs in the classroom were individually interviewed during their internship by the research team members. The duration of the interviews was approximately 45 minutes. They were audio recorded and transcribed. Member check was done with participants to verify the accuracy of their responses to the interview questions.

\subsection{Focus Group Discussions}

In-depth focus group discussions were employed to collect information from the pre-service teachers to better understand their perspectives on inclusive education. The key objective was to elicit from the participants, in two groups, a comprehensive range of views, perceptions and reflections about their experiences on inclusive classroom practices, the challenges they faced, and their preparedness to work with diverse learners. In such planned sessions participants discuss ideas and perceptions focused around a topic of interest (Krueger, 1993). Focus group methodology was selected as a means to identify structures, processes, and activities which promoted and supported pre-service general education teachers to meet the diverse needs of their students including those with special educational needs. The focus group discussion process provided the pre-service teachers an opportunity to share their lived experiences of the inclusive classrooms and schools which could not have been captured through the conventional one-on one interview. Through focus group discussions the participants could "hear themselves and receive feedback from their peers" during discussions led by the research team (Krueger, 1994, p. 239). This enabled the researchers to gather 'rich and thick' data about the level of the pre-service teachers' preparedness and identify the factors influencing the practice of inclusive education. The duration of the focus group discussion was approximately 60 minutes and was audio recorded and transcribed verbatim.

\subsection{Internship Portfolio Reviews}

Researchers' examination of the pre-service teachers' portfolio artifacts was conducted to determine congruency between a defined standard (on diverse learners) of what teachers should know and be able to do and participant portfolio development.

Portfolios can support the affective aspect of student teacher's role, collaboration and work with teachers and parents, as well as academic knowledge and critical thinking. In their portfolios pre-service teachers not only find answers to 'what works' and 'how can I', but they are also encouraged to answer the 'why' questions (Borko, Michalec, Timmons, \& Siddle, 1997; Zollman \& Jones, 1994).

As part of their ten-week internship in schools, pre-service teachers are required to develop a product portfolio that includes samples of evidence specific to the five teacher standards with their own reflections. One if the teacher standards is about diverse learners and pre-service teachers were required to include samples of evidence fulfilling this standard. Pre-service teachers were asked to demonstrate their understanding of how students differ in their 
approaches to learning, and creating instructional opportunities that are adapted to diverse learners, and ensuring intellectual, social, and physical development of the learner. Pre-service teachers included samples of evidence obtained during their internship and included a written reflection on how the standard was addressed. Portfolio entries included work examples of their students, teaching plans, differentiated strategies, resources and reflections of experiences.

Reflections of experiences were used as sources of information for understanding the pre-service teachers' thought processes, knowledge, beliefs, problem solving, decision making, the rationale they used for their actions, and dispositions to teach in inclusive classrooms. Villegas (2007) defined dispositions as, "tendencies for individuals to act in a particular manner under particular circumstances, based on their beliefs" (p. 373). In this definition, the focus is on actions and tendencies indicating a pattern of behavior that may predict future actions. Student reflections were used to assess how pre-service teachers think about teaching, their coursework, and behavior management practices.

\subsection{Data Analysis}

Trained undergraduate research assistants transcribed the audiotaped interviews and focus group discussions verbatim into written text. In addition, hardcopies of the interns' teaching portfolios were collected and analyzed. Reviewing the related standard (i.e. Diverse Learners) provided a clear idea about the requirements. Analyzing the portfolios helped the researchers understand the pre-service teachers' gains during the internship, whether the artifacts selected met the standards, and whether the pre-service teachers were truly reflecting on their practices and future goals or just describing the artifacts produced.

According to Patton (2002), the purpose of the data analysis is to transferring the process of interviews and teaching portfolios into findings. Qualitative research data analysis is the process of bringing order, structure, and meaning to the mass of collected data (Marshall \& Rossman, 1995). It is a search for general statements about relationships among categories of data. Data analysis and interpretation of this study were conducted through (a) organizing interview and focus group discussion transcripts, and the pre-service teachers' portfolios, (b) reading all data and generating categories, themes and patterns, and (c) writing the report according to the findings. The authors carried out a 'member check' exercise, after preliminary findings, and the pre-service teachers were allowed to go through their transcribed interview transcripts and preliminary themes. Furthermore, the participants were asked to add any important information to the summaries and their confirmations were verified.

\section{$4 \quad$ Findings and Discussions}

This section presents and discusses the research findings from the data analysis of individual interviews, focus group discussions, and pre-service teachers' internship portfolios. When the participants confirmed that their reflections and contributions to this investigation were accurately presented, the following final major themes emerged. 


\subsection{Responsibilities of the General Education Teacher in Inclusive schools}

Student diversity in general education classrooms is widening at a progressive and constant rate, and so is the range of accommodations, services, and modifications being required to meet the educational needs of each student. General education teachers are expected to be involved in curricular modifications for all students (Vaughn, Bos, \& Schumm, 2007); however, this is often easier said than done.

\subsubsection{Response to Intervention}

When the participants were asked if they were able to look more closely at the individual learning needs of their students and develop strategies and educational interventions and use them to address the various learning needs, most of them responded that they knew some instructional strategies, but they did not adequately feel comfortable implementing them within their classrooms.

\subsubsection{Curriculum Adaptations and/or Modifications}

While the participants were aware of the different ways in which the general curriculum can be adapted and/or modified to meet the individual needs, they mentioned that they were not trained to determine or utilize adequate strategies and modes of instruction to make sure the student understands and learns what is being taught.

The participants were aware of some of the accommodations and services being required by students with disabilities, such as the preferred seating arrangements in the classroom and use of assistive technology. On the contrary, they did not adequately understand the roles of the paraprofessional and teaching assistant, and the purposes of the required supports and services. Therefore, these pre-service teachers cannot be considered as being prepared for all future situations but will continue to be engaged in continuing professional development.

\subsubsection{Participation in Individual Education Plan (IEP) Development and Implementation}

The shift toward the inclusive classroom and the focus on individualized instruction requires general education teachers to make sure that their general education students and their SEN students achieve academically. While the participants believe that one-on-one instruction is a highly effective practice for students with SEN and their full participation in the IEP process is crucial, they did not make any individualized plans for their students. As the reasons may fluctuate, these future teachers' lack of knowledge on how to implement such plans may play a major role. They responded that they felt they were less than adequately prepared by their teacher education program in the area of IEPs, and that they would not feel comfortable using them in their own classrooms.

Consequently, these future teachers need more training on the purpose, development, and the implementation of the IEP. To enable them to provide input in the creation of the IEP, they need to fully understand the complexities of it, including its goals and objectives in relation to the learner, and to its meaning and the process of development. Hence, teacher preparation programs and professional developers need to consider a great emphasis on the IEP to help novice teachers feel confident in their involvement in its development and implementation. 


\subsection{Coursework and Requirements for Preparation}

While all the participants appeared to be positive towards the overall concept of the inclusion of students with SEN in the regular school and while they were aware of the primary role they, as future general education teachers, are expected to play in the education of these students, they felt hesitant and unprepared to undertake this role. They were also concerned, and their concerns were specifically directed towards students' academic behaviors and performance, and communication as one of the basic functioning skills. This is in accordance with several studies demonstrating that teachers feel unprepared to cope with the students' diverse needs despite their positive attitudes towards inclusion (EADSNE, as cited in Romero-Contreras, S., Garcia-Cedillo, I., Forlin, C., \& Lomeli-Hernandez, K.A., 2013).

They demonstrated their good understanding of differentiated instruction as they believe they were provided with enough information and experience related to its goals and proper use through course work and previous practicum experiences. The samples of their differentiated lesson plans they included in their teaching portfolios provided that the focus was on the learners. They emphasized on student-centered classroom eliminating a one-size-fits-all approach to instruction (Rock, Gregg, Ellis, \& Gable, 2008). They all believed that students are different and they learn differently. However, they demonstrated that they were not properly instructed on how to teach the students with SEN.

Many felt that the coursework and time the college dedicated to addressing the basic knowledge on students with SEN and the practice of inclusion was insufficient to prepare them as general education teachers to successfully meet the needs of their inclusive students. The participants believed that the courses were basic and introductory, and inclusion was a major focus in only one course. Moreover, many participants mentioned that previous teaching experiences were spent in classes that provided limited or no exposure to the reality of inclusive education and the instruction of students with SEN, and they were of the opinion that they should have knowledge on identification of SEN students especially that a large number of such students are not identified in the schools to which the pre-service teachers were allocated.

It seems that teacher education and training programs do little to prepare these teachers (Wasburn-Moses, 2008). Reforms, through which the UAE education system is going through, require general education teachers to take over many of the responsibilities that once only special education teachers held. This requires them to not only be knowledgeable and confident about educational needs and instructional strategies, but also understand and be very well prepared to use the various types of adaptations and modifications to teach and mange students' behavior. Moreover, these pre-service teachers need to develop self-competence. In other words, they "need to believe in themselves as teachers confident of their own particular style and able to evaluate their performance systematically" (Lindop, 1985, p. 165 as cited in Romero-Contreras et al., 2013).

Sosu, Mtika, and Colucci-Gray (2010) highlighted the role of academic course input on inclusion in providing opportunities for pre-service teachers to observe practical exemplars of inclusive curricular and pedagogy. Such input and scaffolding opportunity, through 
theoretical and practical program courses on campus and during field experience, can increase their confidence, competence, knowledge and skills essential to successful implementation of inclusive pedagogy and consequently lead to more favorable attitudes towards inclusion (Villa, Thousand, Meyers \& Nevin., 1996; Beh-Pajooh, 1992)). Research has also suggested that partnership and collaboration between initial teacher education programs and schools is required for the provision of such scaffolding opportunities (Agrawal, Epstein, Oyler, Oppenheim, \& Sonu., 2010) to be prepared for the inclusive classroom reality.

\subsection{The Collaboration of Special and General Education Teachers}

The participants were working exclusively with their mentor teachers, who were general education teachers, when teaching their students. They were looking for opportunities to share ideas with special education teachers and the different service providers and professionals like physical therapists, and speech and language therapists. Collaboration would not only have developed the pre-service teachers' existing knowledge of curriculum and effective instructional methods, but it would have also encouraged them to consider special educators as a resource to help them improve their knowledge and skills required to successfully meet all the challenges they would ultimately face (Cahill \& Mitra, 2008), especially that they lack pre-service special education coursework. The sharing of ideas and collaborative relationships would help future general education teachers feel comfortable to interact with the special education educators when they work in the school system, and would also allow them better support students with SEN.

Collaboration and shared responsibility between general and special education can only become a reality if all the educational disciplines work together at the pre-service level. Higher education programs should not only demonstrate collaboration between special education and general education colleges, but also provide several opportunities for special and general education teacher candidates to interact within their preparation programs (Arthaud, Aram, Breck, Doelling, \& Bushrow, 2007).

For inclusion to succeed, Garriott, Miller, and Snyder (2003) stated:

...general education pre-service teachers [should] be given the opportunity to openly dialogue with experienced general educators, special educators, and university faculty who acknowledge the difficulties in implementing inclusion but never lose sight of the ultimate goal--inclusion for all students (p. 51).

\subsection{The Disposition to Teach in Inclusive Classrooms}

This study demonstrates the importance of quality school experiences in developing the disposition to teach in inclusive settings. From the qualitative analysis of the data, the following constructs were identified:

\subsubsection{Empathy}

The ability to empathize and understand students' perspectives is essential in teaching, especially when teaching students with disabilities (Ahan \& Stifter, 2006). In the present study, the participants appeared to be empathetic; caring sincerely about all students and paying close 
attention to their learning needs. They appreciated student differences and adjusted their lessons and behavior management plans based on students' diverse needs. The focus of their thinking was the individual needs and differentiating instruction. This opportunity to develop empathy for students with disabilities was probably reflected in some participants' intentions to go into special education for their careers.

\subsubsection{Classroom Behavior Management}

The participants' comments on classroom behavior management throughout their reflections and their responses to a prompt to discuss any behavior management strategies used in the classrooms demonstrated the effectiveness of the management strategies being employed and their contribution to the absence of behavior problems. In addition, the participants discussed the importance of antecedents and consequences to behavior management, and their different strategies and techniques to keep learning fun, active, and instructional.

\subsubsection{Reflective Analysis}

All the participants engaged in reflective analysis throughout their internship experience and they showed varying degrees of abilities to think back on situations and analyze the related variables for the purpose of learning from them. Their reflective analysis resulted in higher order thinking about their practices as teachers. They used their reflections to develop professionally.

\subsubsection{Collaboration}

The participants said that they began to understand the importance of collaboration to better meet the needs of all students. They realized the importance of parental involvement to help students succeed. Moreover, they began to examine the challenges to effective collaboration. For example, some participants were looking for opportunities to communicate with the special education teachers in order to modify lessons in their own classrooms to meet the needs of students with SEN. Their comments reflect their understanding of the value and need for effective collaboration and their awareness of the challenges in developing these relationships.

\subsection{Challenges and Barriers}

The diversity of the $21^{\text {st }}$ century classroom makes teaching a challenging task for future teachers especially if certain changes are required in the classroom and school environment to meet the needs of students with SEN (Florian, 1998). The participants pointed out the following:

- Lack of resources, both human and material (e.g. classroom assistants, SEN staff, specialists, differentiated teaching packages, hearing, reading and speech support).

- Large class sizes as being a challenge, and reported the need for smaller ones, especially those with included SEN students.

- Lack of co-ordination and lack of co-operation between the general and special educators. Such points raised major issues about the quality of the school practices. 
- Time restraints and lack of needed support resulted in some participants hesitant to implement individualized instruction while others do not even know how to apply it.

As the participants reported that the structure of the schools does not allow successful accommodation of students with SEN in terms of resources, human and material, they appeared convinced that proper funding and change in the organization of the school (systems change) are required if inclusion is to be successfully implemented.

The stated challenges and barriers pointed out by the participants raise major issues about their preparation; in asking for more knowledge, more practice, more experience with SEN students, it is evident they are making a clear statement that the current Bachelor of Education Program does not adequately prepare them to meet diverse learning needs of students whom they will have to address as newly qualified future teachers.

\section{Conclusion}

Changes in international education and the Emirati society place new demands on the teaching profession. These changes stress the need for teacher education programs to have an organized approach linking courses and field experiences within a conceptual framework leading to congruence in definition, purpose, and goals for the teaching experience, and help teachers acquire new knowledge and skills and develop them continuously. Additionally, more needs to be done regarding the way in which general education teachers are prepared to meet the diverse needs of all students. It is also imperative that research and development groups related to practices are set up in order to guarantee innovation and the educational system are to move towards genuinely meeting the needs of all students and fulfilling the promise of inclusion.

\section{Acknowledgement}

The authors would like to express their sincere appreciation to Mariam Al Hammadi for her assistance in data collection and contributions to this research study.

\section{References}

Abu Dhabi Education Council (2010). Special education. Retrieved on June 1, 2015 from https://www.adec.ac.ae/en/Parents/SpecialEducation/Pages/default.aspx

Agarwal, R., Epstein, Oyler, C., Oppenheim, Sonu, D. (2010). From ideal to practice and back again: Beginning teachers teaching for social justice. Journal of Teacher Education, 61(3), 237-247. http://dx.doi.org/10.1177/0022487109354521

Ahan, H. J., \& Stifter, C. (2006). Child care teachers' response to children's emotional expression. Early Education and Development, 17(2), 253-270. http://dx.doi.org/10.1207/s15566935eed1702_3 
Al Ahbabi, A. (2009). K-12 special and general education teacher's attitudes toward the inclusion of students with special needs in general education classes in the United Arab Emirates (UAE). International Journal of Special Education, 24(2), 42-54.

Arthaud, T. J., Aram, R. J., Breck, S.E., Doelling, J. E., \& Bushrow, K. M. (2007). Developing collaboration skills in pre-service teachers: A partnership between general and special education. Teacher Education and Special Education, 30, 1-12. http://dx.doi.org/10.1177/088840640703000101

Boger, C., \& Boger, D. (2000). Preservice teachers' explanations of their teaching behaviour, Journal of Instructional Psychology, 27, 217-223.

Borko, H., Michalec, P., Timmons, M., \& Siddle, J. (1997). Student teaching portfolios: A tool for promoting reflective practice. Journal of Teacher Education, 48, 345-357. http://dx.doi.org/10.1177/0022487197048005004

Cahill, S. M. \& Mitra, S. (2008). Forging collaborative relationships to meet the demands of inclusion. Kappa Delta Pi Record, 44, 149-51. http://dx.doi.org/10.1080/00228958.2008.10516513

Cardona, C. M. (2009). Teacher education students' beliefs of inclusion and perceived competence to teach students with disabilities in Spain. Journal of the International Association of Special Education, 10(1), 33-41. http://dx.doi.org/10.1.1.469.863\&rep=rep1\&type=pdf\#page=35

Carroll, A., Forlin, C., \& Jobling, A. (2003). The impact of teacher training in special education on the attitudes of Australian pre-service general educators towards people with disabilities. Teacher Education Quarterly, 30(3), 65-79.

Constitution of the UAE. (n.d.) Retrieved on June 12, 2015 from http://www.refworld.org/pdfid/48eca8132.pdf

Cook, B. G., \& Cook, L. (2004). Bringing science into the classroom by basing craft on research. Journal of Learning Disabilities, 37, 240-247. http://dx.doi.org/10.1177/00222194040370030901

Cook, B. G., Landrum, T. J., Tankersly, M., \& Kauffman, J. M. (2003). Bring research to bear on practice: Effecting evidence-based instruction for students with emotional or behavioral disorders. Education and Treatment of Children, 26, 345-361.

Florian, L. (1998). An examination of the practical problems associated with the implementation of inclusive education policies. Support for Learning, 13, 105-108. http://dx.doi.org/10.1111/1467-9604.00069

Florian, L., \& Rouse, M. (2009). The inclusive practice project in Scotland: Teacher education for inclusive education. Teaching and Teacher Education, 25(4), 594-601. http://dx.doi.org/10.1016/j.tate.2009.02.003

Forlin, C. (2007). A collaborative, collegial, and a more cohesive approach to support 
educational reform for inclusion in Hong Kong. Asia Pacific Education Review, 8(2), 1-11. http://dx.doi.org/10.1080/1359866x.2014.906564

Gaad, E. (2011). Inclusive education in the Middle East. New York: Routledge.

Garriott, P.P., Miller, M., \& Snyder, L. (2003). Pre-service teachers' beliefs about inclusive education: What should teacher educators know? Action in Teacher Education, 25, 48-54. http://dx.doi.org/10.1080/01626620.2003.10463292

Hagger, H., \& McIntyre, D. (2006). Learning teaching from teachers. Maidenhead: Open University Press.

Jordan, A., Schwartz, E., \& McGhie-Richmond, D. (2009). Preparing teachers for inclusive classrooms. Teaching and Teacher Education, 25(4), 535-542.

Krueger, R. A. (1993). Quality control in focus group research. In D. L. Morgan (Ed.), Successful focus groups: Advancing the state of the art (pp. 65-85). Newbury Park, CA: Sage Publications.

Krueger, R. A. (1994). Focus groups: A practical guide for applied research (2nd Ed.). Thousand Oaks, CA: Sage Publications.

Kvale, S. (1996). Interviews. An introduction of qualitative research interviewing. Thousand Oaks: Sage Publications.

Lancaster, J., \& Bain, A. (2007). The design of inclusive education courses and the self-efficacy of preservice teacher education students. International Journal of Disability, Development and Education, 54(2), 245-256. http://dx.doi.org/10.1080/10349120701330610

Lincoln, Y. S., \& Guba E. G. (1985). Naturalistic Inquiry, Sage, Beverly Hills, CA.

Loreman, T., Deppeler, J., \& Harvey, D. (2005). Inclusive Education: A practical guide to supporting diversity in the classroom. Sydney: Allen and Unwin.

Marshall, C., \& Rossman, G. (1995). Designing qualitative research (2nd ed.). Thousand Oaks, CA: Sage Publications, Inc.

Maxwell, J. A. (1996). Qualitative research design: An interactive approach. California: SAGE Publications.

Ministry of Education (MOE). (2010). School for All: General rules for the provision of special education programs and services (Public \& Private Schools). UAE: Dubai. Retrieved from http://www.moe.gov.ae/English/Documents/Rules/SNrulesEn.pdf

Patton, M. Q. (1990). Qualitative evaluation and research methods. Newbury Park, CA: Sage Publications, Inc.

Patton, M. Q. (2002). Qualitative evaluation and evaluation methods. Thousand Oaks, CA: Sage Publications, Inc. 
Rashed, R., \& Ahmed, A. (1995). Statistical abstract of social affairs. Dubai, UAE: Ministry of Labor and Social Affairs.

Rice, J. K. (2003). Teacher quality: Understanding the effectiveness of teacher attributes. Washington DC, Economic Policy Institute.

Rock, M. L., Gregg, M., Ellis, E. \& Gable, R. A. (2008). REACH: A framework for differentiating classroom instruction. Preventing School Failure, 52, 31-47. http://dx.doi.org/10.3200/PSFL.52.2.31-47

Romero-Contreras, S., Garcia-Cedillo, I., Forlin, C., \& Lomeli-Hernandez, K.A. (2013). Preparing teachers for inclusion in Mexico: how effective is this process? Journal of $\begin{array}{lll}\text { Education } & \text { for } & \text { Teaching, }\end{array}$ http://dx.doi.org/10.1080/02607476.2013.836340

Rose, R. (2007). Curriculum considerations in meeting special education needs. In International Handbook of Special Education (pp. 295-306), London, Sage.

Salamanca Statement and Framework for Action, UNESCO, 1994. Ref: ED-94/WS/1 8 Retrieved on January 2016 from http://www.inclusion.com/artsalamanca.html

Sanders, W., \& Horn, S. (1998). Research findings from the Tennessee Value-Added Assessment System (TVAAS) database: Implications for educational evaluation and research. Journal of Personnel Evaluation in Education, 12(3), 247-256. http://dx.doi.org/10.1023/A:1008067210518

Savolainen, H. (2009). Responding to diversity and striving for excellence: The case for Finland. In Acedo C. (ed.), Prospects Quarterly Review of Comparative Education, 39(3), September 2009.

Schwartz, S. E., \& Karge, B. D. (1996). Human diversity: A guide for understanding. New York: McGraw-Hill.

Spandagou, I., Evans, D., \& Little, C. (2008). Primary education pre-service teachers' attitudes on inclusion and perceptions on preparedness to respond to classroom diversity. Paper presented at AARE 2008 International Education Research Conference, Australia.

Strauss, A., \& Corbin, J. (1990). Basics of Qualitative Research: Grounded Theory Procedures and Techniques, Sage, Thousand Oaks, CA

Talvite, U., Peltokallio, L., \& Mannisto, P. (2000). Student-teachers' views about their relationships with university supervisors, cooperating-teachers and peer student teachers. Scandinavian Journal of Educational Research, 44, 79-87. http://dx.doi.org/10.1080/713696662

UAE Cabinet. (2010). Constitution of UAE. Retrieved on June 15, 2015 from http://uaecabinet.ae/en/uaegovernment/pages/uae-constitution.aspx

Vaughn, S., Bos, C., \& Schumm, J. S. (2007). Teaching students who are exceptional, diverse, and at risk in the general education classroom (4th Ed.). New York: Pearson Education, 
Inc.

Villa, R., Thousand, J., Meyers, H., \& Nevin, A. (1996). Teacher and administrator perceptions of heterogenous education. Exceptional Children, 63, 29-45. http://dx.doi.org/10.1177/001440299606300103

Villegas, A. M. (2007). Dispositions in teacher education: a look at social justice. Journal of Teacher Education, 58, 370-380. http://dx.doi.org/10.1177/0022487107308419

Voltz, D., Brazil, N., \& Ford, A. (2001). What matters most in inclusive education: A practical guide for moving forward. Intervention in School and Clinic, 37(1), 23-30. http://dx.doi.org/10.1177/105345120103700105

Wasburn-Moses, L. (2008). Teacher candidates' understandings of instructional strategies in a changing field. Action in Teacher Education, 29, 66-82. http://dx.doi.org/10.1080/01626620.2008.10463470

Wilson, S., Floden, R., \& Ferrini-Mundy, J. (2001). Teacher preparation research: An insider's view from the outside. Journal of Teacher Education, 53(3), 90-204. http://dx.doi.org/10.1177/0022487102053003002

Zollman, A., \& Jones, D. (1994, Feb.). Accommodating assessment and learning: Utilizing portfolios in teacher education with preservice teachers. Paper presented at the annual conference of the Research Council on Diagnostic and Prescriptive Mathematics, Fort Worth, TX. (ERIC Document Reprod. Serv. No. ED 368 551).

\section{Copyright Disclaimer}

Copyright for this article is retained by the author(s), with first publication rights granted to the journal.

This is an open-access article distributed under the terms and conditions of the Creative Commons Attribution license (http://creativecommons.org/licenses/by/3.0/). 